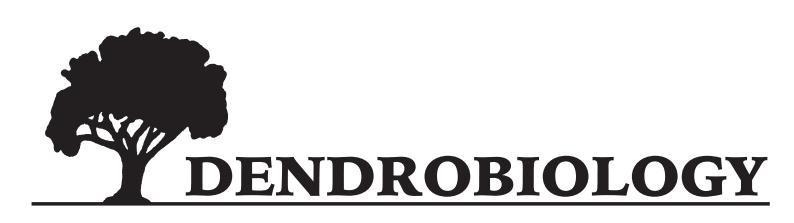

2018, vol. $80,91-100$

http://dx.doi.org/10.12657/denbio.080.009

\author{
František Lorenc, Vitězslava Pešková, Roman Modlinger, Libor Mrnka, \\ Ivana Tomášková, Petr Šenfeld, Marek Turčáni
}

\title{
Fine roots of Picea abies compensate for drought stress in the rainfall reduction experiment
}

Received: 13 July 2018; Accepted: 19 November 2018

\begin{abstract}
This study evaluates the influence of repeated artificial drought stress on the fine root characteristics - including ectomycorrhizae - of Norway spruce [Picea abies (L.) Karst]. The experimental site consisted of two plots in a mature spruce monoculture stand. The water regime at parts of both plots was regulated by shelters and an isolation trench during vegetation season (spring to autumn) since 2010. Root samples were collected during autumn in 2010, 2012, and 2013. Root analyses revealed the effect of drought stress on mycorrhizal root tips changed over time. While a density of active mycorrhizae was about 34\% lower in drought-stressed areas compared to nonstressed (control) areas in 2010, it increased by $15 \%$ in 2012 and by $22 \%$ in 2013 over both plots. We observed the less pronounced effect of drought on a proportion of active mycorrhizae, but it generally followed the pattern of active mycorrhizae density. The density of nonactive mycorrhizae was not influenced by drought but significantly fluctuated during the course of the experiment. Other root characteristics such as the dry mass of fine roots $(<1 \mathrm{~mm})$, the specific length of fine roots $(<1 \mathrm{~mm})$ and the composition of the ectomycorrhizal community (primarily dominated by Amphinema byssoides, Tylospora fibrillosa, Tylopilus felleus, and Cenococcum geophilum) were also not significantly influenced by drought. Our results indicate the ability of Norway spruce fine roots to compensate for repeated drought stress of the intermediate intensity.
\end{abstract}

Keywords: climate change, community, ectomycorrhiza, Norway spruce, WinRhizo

Addresses: F. Lorenc, V. Pešková, R. Modlinger, I. Tomášková, P. Šenfeld, M. Turčáni, Czech University of Life Sciences Prague, Faculty of Forestry and Wood Sciences, Kamýcká 129, 16500 Praha 6 - Suchdol, Czech Republic

F. Lorenc, Forestry and Game Management Research Institute, Strnady 136, 25202 Jíloviště-Strnady, Czech Republic, e-mail: lorenc@vulhm.cz

L. Mrnka, Institute of Botany of the Czech Academy of Sciences, Zámek 1, 25243 Průhonice,

Czech Republic

\section{Introduction}

Due to ongoing climatic changes, European forests will probably face more frequent and intense weather fluctuations. Predictions show it will entail both long periods of drought and torrential rainfall (Lindner et al., 2010). Under these conditions Norway spruce [Picea abies (L.) Karst.] is at risk of substantially decreasing growth (Altman et al., 2017), as well as more natural infection by parasitic fungi, especially annosum root rot (Heterobasidion sp.) (Lindberg \& Johannson, 1992) and honey fungus (Armillaria sp.) (Lindner et 
al., 2008) or by herbivorous insects (Økland \& Berryman, 2004). Norway spruce has unusually low resistance to drought compared to other common forest species such as beech or oaks, especially when grown in monocultures (Pretzsch et al., 2013).

Drought influences tree physiology on several levels and lead to a decrease of storage compounds, a decrease of leaf area index together with cambial activity, and an increase of fine roots' mortality (Bréda \& Badeau, 2008). The general response to drought includes increased root to shoot ratio, the shift of fine roots into deeper (mineral) soil layers and a shorter lifespan. Main root traits such as specific root length or root tissue density remained unchanged (Brunner et al., 2015).

Mycorrhizal symbiosis seems to be one of the key factors enabling increased ecosystem resilience to climatic extremes (Kivlin et al., 2013). Mycorrhiza can alleviate drought stress due to the roots' increased absorption surface, efficient water distribution using mycelial fibers, increased hydraulic conductivity at the soil-root interface and augmented expression of aquaporins (Bréda et al., 2006; Brunner et al., 2015). In comparison to non-mycorrhizal plants, mycorrhizal plants usually have higher values of proline (osmoprotectant and an effector molecule alleviating many different kinds of stress including drought) and also lower values of lipid peroxidases which play a role in oxidative stress reactions (Porcel \& Ruiz-Lozano, 2004; Bois et al., 2006). During low or intermediate drought stress, ectomycorrhizal plants are usually better supplied by water than nonmycorrhizal plants, resulting in lower soil water content near the root system. Contrary, during severe drought stress, water can flow from the plants to soil (Gryndler et al., 2004). As individual mycorrhizal fungi differ in their drought stress tolerance (di Pietro et al., 2007), the composition of mycorrhizal communities (and hence their physiological function) can be substantially influenced by drought (Shi et al., 2002). Koide et al. (2008) suggested that reduced carbon allocation via their tree host (which occurs due to drought) may have negative impacts on fungi with high demand for carbon from photosynthesis and instead favor fungi with enhanced saprotrophic potential. Common ectomycorrhizal fungus Cenococcum geophilum seems to be particularly resistant to drought (di Pietro et al., 2007) and possesses relatively high saprotrophic abilities (Peter et al., 2016) favoring it for drought conditions. The ecological importance of ectomycorrhizal fungi species is often regarded as being proportional to the number of ectomycorrhizal tips, but characteristics of extraradical mycelium also play a significant role (Landeweert et al., 2003). The development of fine roots and ectomycorrhizae is influenced by factors internal to the plant (e.g., host genotype, chemistry, growth rate, other present symbionts), and various environmental conditions including soil, climate and season with mutual interconnection of some of them (Buée et al., 2005; Kernaghan, 2005; Korkama et al., 2006; Piculell et al., 2008). Crucial factor is $\mathrm{pH}$, which substantially influences the number of ectomycorrhizal roots (Lehto, 1994; Nowotny et al., 1998) and the representations of individual ectomycorrhizal species (Von Alten \& Rossbach, 1989; Kjøller \& Clemmensen, 2009).

Most studies dealing with fine roots (including ectomycorrhizae) in relation to water availability in the soil profile have been short-term (involving only one drought period) and often done under artificial conditions (Lehto \& Zwiazek, 2011). The influence of long-term and repeated drought periods on ectomycorrhizae under natural conditions, however, is not well known. Cudlín et al. (2007) recommended using a number of root tips, and a density of fine roots based on dry weight, root length, or soil volume as indicators of drought impact.

The objective of this study was to determine an influence of repeated drought stress on selected characteristics of fine spruce roots, including the density of mycorrhizal root tips and the composition of ectomycorrhizal fungal community in the mature spruce stand. To achieve the goal we compared fine root characteristics of trees artificially stressed by drought with those of control unstressed trees. We assumed that drought would generally negatively influence tested root characteristics and that the community of ectomycorrhizal fungi would change in favor of more drought-tolerant species. We also expected a partial adaptation of tested trees to repeated exposure to drought over the tested period, i.e., recovery of some of the measured characteristics (e.g., the proportion of active mycorrhizal tips) while the long-standing change of other characteristics (e.g., dry mass of fine roots).

\section{Methods}

The experiment was conducted at Kostelec nad Černými lesy (the Czech Republic, 4957'56"N, $\left.14^{\circ} 51^{\prime} 17^{\prime \prime} \mathrm{E}\right)$. Mean annual temperature at the location is $9^{\circ} \mathrm{C}$ and mean annual precipitation is $527 \mathrm{~mm}(\mathrm{Za}-$ jíčková et al., 2011). Soil type at the location is modal cambisol (Němeček et al., 2004) with mean $\mathrm{pH}$ value 3.74 (measured in water solution, according to ISO/ DIS 10390, 1994). The location consisted of a uniform-age 80 years old monoculture spruce stand. The experiment involved two research plots (P1 and P2) with 40 trees per plot. Each of these research plots was divided into two parts: drought-stressed and control. The water regime in the drought-stressed parts was controlled using shelters with a plastic cover at a height about $1.8 \mathrm{~m}$, which covered an area 
of $25 \times 25 \mathrm{~m}$ on each of these subplots and conducted precipitation water outside from the plots with drought regime. The drought-stressed subplots were sheltered from the beginning of May to mid-October every year during 2010-2013. The water regime of these sites was also modified by the construction of an isolation trench to prevent subsurface draining of water to them. The water potential in all four parts of the plots (both control and stressed ones) was measured using total 48 GB-2 gypsum sensor blocks from Delmhorst Instrument Co. (Montville, $\mathrm{NJ}$, USA) distributed in a regular square network in soil at depth $15 \mathrm{~cm}$ and it was recorded automatically at $1 \mathrm{~h}$ intervals.

Soil samples were collected by a soil auger with an inner diameter of $6 \mathrm{~cm}$ to a depth of $15 \mathrm{~cm}$ (sample volume ca. $424 \mathrm{~cm}^{3}$ ), during autumn in 2010, 2012, and 2013: ten samples per plot * year (i.e., 40 samples per year, 120 samples in total). Samples from mineral soil layers were not analyzed due to the low amount of present fine roots. After collection, the soil cores were placed in a refrigerator until further processed. Processing of all collected soil samples included root extraction according to Pešková and Soukup (2006). Spruce roots were manually extracted from the soil using tweezers and dissecting needles. Roots of other plants which could not be identified were removed.

In samples collected in 2010 and 2012, the density of active and nonactive mycorrhizae, the proportion of active mycorrhizae and dry mass of roots were evaluated together with specific root length determined using a WinRhizo instrument (Regent Instruments Inc., Canada). An overview of the analyzed root parameters is given in Table 1. All root parameters were using fine roots with a diameter up to $1 \mathrm{~mm}$ because these roots respond most sensitively to environmental factors, and they are better represented in a soil auger than larger-diameter roots (Pešková \& Soukup,

Table 1. Mycorrhizal and root characteristics evaluated

\begin{tabular}{llc}
\hline Abbreviation & \multicolumn{1}{c}{ Variable } & Unit \\
\hline ActM & $\begin{array}{l}\text { Density of active mycorrhizae (num- } \\
\text { ber of active mycorrhizal tips divided } \\
\text { by root length in centimetres) }\end{array}$ & $\mathrm{cm}^{-1}$ \\
NactM & $\begin{array}{l}\text { Density of nonactive mycorrhizae } \\
\text { (number of nonactive mycorrhizal tips } \\
\text { divided by root length in centimetres) }\end{array}$ & $\mathrm{cm}^{-1}$ \\
\% ActM & $\begin{array}{l}\text { Proportion of active mycorrhizae } \\
\text { (number of active mycorrhizal tips }\end{array}$ & $\%$ \\
& $\begin{array}{l}\text { divided by total number of mycor- } \\
\text { rhizal tips) }\end{array}$ & \\
DM<1 mm & $\begin{array}{l}\text { Dry mass of roots with diameter up } \\
\text { to 1 mm }\end{array}$ & $\mathrm{g}$ \\
spec_length & $\begin{array}{l}\text { Specific root length (length of roots } \\
\text { with diameter up to 1 mm divided by } \\
\text { dry mass of roots with diameter up to }\end{array}$ & \\
& $\begin{array}{l}1 \text { mm) } \\
\text { Representation of a molecularly deter- }\end{array}$ & $\%$ \\
Mycorrhizal & $\begin{array}{l}\text { mined mycorrhizal fungus } \\
\text { fungus species }\end{array}$ & \\
\hline
\end{tabular}

2006). We also intended to keep analyses of fine roots consistent with previously acquired and published data (Pešková et al., 2015). After extraction, roots were stored in a fixative solution of $2.5 \%$ glutaraldehyde until further processed. Active and nonactive mycorrhizae were evaluated according to the methodology described by Pešková and Soukup (2006) (Table 1). From each sample, 20 root segments with main root length of $5 \mathrm{~cm}$ were randomly selected. The total length of each segment was calculated as the primary root length plus the root length of its branching systems. On each selected root segment, mycorrhizal tips were counted and assessed under a stereomicroscope at 40x magnification. Tips with a smooth surface, high turgor pressure, well developed hyphal sheaths and lacking radical hair, were classified as active mycorrhizae. Tips with wrinkled surface, low turgor pressure and without hyphal sheats were classified as nonactive mycorrhizae (Holuša et al., 2009). Afterward, dry mass of roots (at $105^{\circ} \mathrm{C}$ ) was determined.

For the evaluation of specific root length (Table 1) by WinRhizo, the dissected roots were scanned and then analyzed. The total root length was divided by root dry matter weight to determine specific root length (Konôpka \& Takáčová, 2010).

Samples collected in 2013 were divided into two parts. The first part was processed as described in the above section. In the second part, the species composition of ectomycorrhizal fungi in roots from the organic soil layer was determined using morphotyping and subsequent molecular analyses. For the analyses, fine roots with diameter up to $2 \mathrm{~mm}$ (commonly used threshold in mycorrhizal research) were selected. These roots were stored in 35\% ethanol and analyzed under a stereomicroscope (Olympus SZX12). Ectomycorrhizal tips were separated into morphotypes on the basis of branching type, color, hyphal sheath characteristics, the presence of extra-radicular mycelia and rhizomorphs (Agerer, 1987-2012). An average of 300 mycorrhizal tips was analyzed per sample though only approx. 140 mycorrhizal tips/ sample were turgescent and undamaged and thus suitable for sorting to morphotypes. Representative mycorrhizal tips of each morphotype were separated and kept in $35 \%$ ethanol at $4^{\circ} \mathrm{C}$ until used for molecular determination.

At least two representatives of each morphotype (preferentially from different subplots) were used for subsequent molecular analyses. DNA was isolated from individual mycorrhizal root tips using the DNeasy PowerPlant Pro kit (Quiagen, USA) and amplified using polymerase chain reaction (PCR) based on their rDNA region. PCR conditions followed the work of Vohník et al. (2013). Semi-nested PCR was used with primers ITS1F and ITS4 (White et al., 1990; Gardes \& Bruns, 1993) in the first run and with 
primers ITS1-ITS4 in the second run. Purification and sequencing of PCR products were done by Macrogen Europe (Amsterdam, the Netherlands). The obtained sequences were BLAST searched against the nucleotide database in GenBank (NCBI) and sequence similarity $\geq 97 \%$ was used as a threshold for species identification. After molecular identification of each morphotype, the overall relative proportion of ectomycorrhizal species was calculated (unidentified morphotypes constituted less than $6 \%$ of the total number of morphotypes). The sequences were submitted to the NCBI GenBank database (accession numbers MK050091, MK050546-MK050552, and MK050633-MK050642).

Statistical evaluation of the density of active mycorrhizae, the density of nonactive mycorrhizae, and proportion of active mycorrhizae was performed using statistical software R (R Core Team, 2015). We used a linear mixed effect model (LME) fitted by restricted maximum likelihood (REML), where mycorrhizal parameters (ActM, NactM,\% ActM) were used as the dependent-variables, year as a continuous variable and drought stress as a fixed factor. Both independent variables were nested in the plot variable. In the evaluation of the model were used approaches according to Crawley (2007) and Pekár \& Brabec (2012).

\section{Results}

Drought stress caused by a rainfall reduction in our study reached the intermediate intensity and was not uniform over the tested plots. In autumn of 2010, soil water potential reached the lowest values in the drought-stressed part of plot P2 $(-1.1 \mathrm{MPa})$ in comparison to others $(-0.5 \mathrm{MPa}$ in the droughtstressed part of plot P1, $-0.1 \mathrm{MPa}$ at control part of plot P1, $-0.2 \mathrm{MPa}$ at control part of plot P2) (Turčáni et al., 2010). In the following years water potential was also lower on both stressed parts compared to the control ones but due to missing data we cannot present reliable average values.
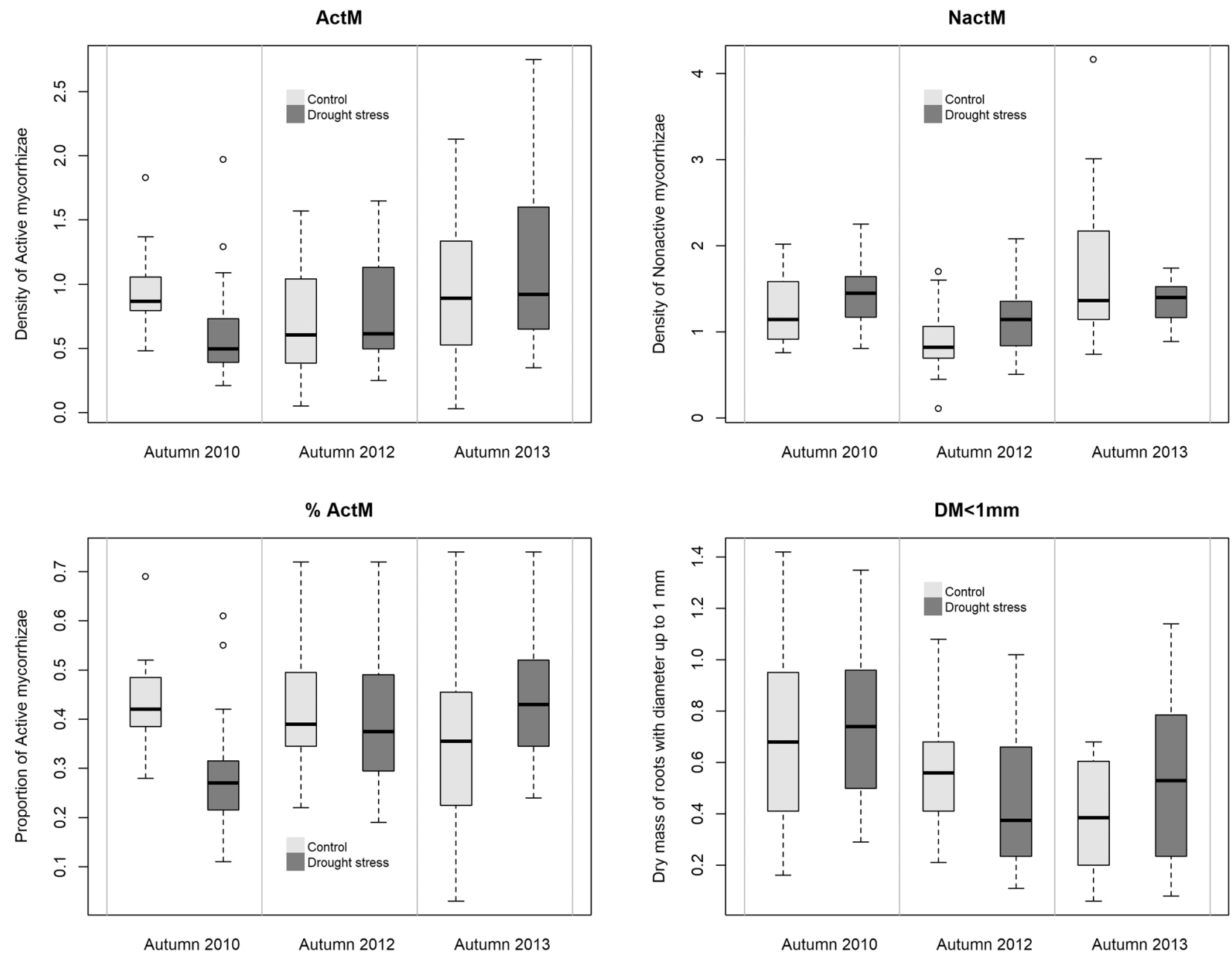

Fig. 1. Density of active mycorrhizae, density of nonactive mycorrhizae, proportion of active mycorrhizae and dry mass of roots up to $1 \mathrm{~mm}$ in stressed and control parts over the both plots in every sampled yeas. Every column consists of 20 samples. Central band - median, box $-1^{\text {st }}$ and $3^{\text {rd }}$ quartiles, whiskers -1.5 multiple of interquartile range, dots - above 1.5 multiple of interquartile range 
Table 2. Effect of tested variables (year, drought stress) on root characteristics of Norway spruce. Linear mixed effect model was used for statistical evaluation. ActM density of active mycorrhizae, NactM - density of nonactive mycorrhizae, $\%$ ActM - proportion of active mycorrhizae, DF - degrees of freedom, F - statistical F-test values, $\mathrm{p}$ - singificance level: ${ }^{*} \mathrm{p}<0,05 ;{ }^{* *} \mathrm{p}<$ 0,$01 ;{ }^{* * *} \mathrm{p}<0,001$

\begin{tabular}{clcrc}
\hline $\begin{array}{c}\text { Dependent } \\
\text { variable }\end{array}$ & Independent variables in model & $\mathrm{DF}$ & $\mathrm{F}$ & $\mathrm{p}$ \\
\hline Actm & Intercept) & 1 & 52.83 & $* * *$ \\
& year & 2 & 5.34 & $* *$ \\
& drought stress & 1 & 0.01 & 0.93 \\
& year : drought stress & 2 & 3.44 & $*$ \\
NactM & (Intercept) & 1 & 851.04 & $* * *$ \\
& year & 2 & 11.05 & $* * *$ \\
& drought stress & 1 & 0.23 & 0.63 \\
& year : drought stress & 2 & 4.82 & $* *$ \\
ActM & (Intercept) & 1 & 114.19 & $* * *$ \\
& year & 2 & 1.47 & 0.23 \\
& drought stress & 1 & 1.38 & 0.24 \\
& year : drought stress & 2 & 6.65 & $* *$ \\
\hline
\end{tabular}

The density of active mycorrhizae has significantly changed through the evaluated years (LME: $\mathrm{n}=119$; $\mathrm{df}=2 ; p<0.01$; Table 2). A decrease of ActM in 2012 and an increase in 2013 was observed contrary to 2010 values. The density of active mycorrhizae in drought-stressed and control parts followed the general trend of the changes over evaluated years, so we did not detect observe the statistically significant difference between them (Table 2). On the other hand, time course of changes in ActM was significantly different between drought stressed and control parts (LME: $\mathrm{n}=119$; $\mathrm{df}=2 ; p<0.05$; Table 2). In drought stressed plots fast decrease of ActM in reaction to water deficiency was followed by steady increase of active root tips density to the levels exceeding the original values in 2010. In the control parts only transient decrease of ActM was detected in 2012 followed by an increase of this parameter to the levels measured in 2010. Overall, the density of active mycorrhizae was about $34 \%$ lower in drought-stressed areas compared to nonstressed (control) areas in 2010, but it increased by $15 \%$ in 2012 and by $22 \%$ in 2013 over both plots (Fig. 1; Supplementary Table 1).

Density of nonactive mycorrhizae was highly different between the sampling years (LME: $\mathrm{n}=119$; $\mathrm{df}$ $=2 ; p<0.001$; Table 2). In 2012, it was about 25\% lower than in 2010 and in 2013 about $51 \%$ greater than in 2012 over both plots. Effect of drought stress on the density of nonactive mycorrhizae was not statistically significant (Table 2), due to the high variance of both control and drought stressed values. The density of nonactive mycorrhizae differed in drought-stressed plots and control plots through the tested period of time (LME: $\mathrm{n}=119 ; \mathrm{df}=2 ; p$ $<0.01$; Table 2), where more pronounced changes
Table 3. Mean \pm standard deviation of specific root length (spec_length) and percentage representation of individual ectomycorrhizal species of fungi in 2013. N: number of samples

\begin{tabular}{|c|c|c|c|c|}
\hline Variable & Drought stress & $\mathrm{N}$ & Plot & 2013 \\
\hline \multirow{6}{*}{ spec_lenght } & no & 10 & $\mathrm{P} 1$ & $1655 \pm 319$ \\
\hline & no & 10 & P2 & $1977 \pm 669$ \\
\hline & no & 20 & $\mathrm{P} 1+\mathrm{P} 2$ & $1816 \pm 556$ \\
\hline & yes & 9 & P1 & $1482 \pm 616$ \\
\hline & yes & 9 & P2 & $1449 \pm 460$ \\
\hline & yes & 18 & $\mathrm{P} 1+\mathrm{P} 2$ & $1465 \pm 528$ \\
\hline \multirow[t]{6}{*}{ A. byssoides } & no & 10 & $\mathrm{P} 1$ & $42 \pm 18$ \\
\hline & no & 10 & $\mathrm{P} 2$ & $44 \pm 22$ \\
\hline & no & 20 & $\mathrm{P} 1+\mathrm{P} 2$ & $43 \pm 19$ \\
\hline & yes & 10 & P1 & $50 \pm 21$ \\
\hline & yes & 10 & P2 & $46 \pm 23$ \\
\hline & yes & 20 & $\mathrm{P} 1+\mathrm{P} 2$ & $48 \pm 22$ \\
\hline \multirow[t]{6}{*}{ T. felleus } & no & 10 & $\mathrm{P} 1$ & $11 \pm 11$ \\
\hline & no & 10 & P2 & $6 \pm 7$ \\
\hline & no & 20 & $\mathrm{P} 1+\mathrm{P} 2$ & $8 \pm 9$ \\
\hline & yes & 10 & $\mathrm{P} 1$ & $4 \pm 7$ \\
\hline & yes & 10 & P2 & $11 \pm 11$ \\
\hline & yes & 20 & $\mathrm{P} 1+\mathrm{P} 2$ & $7 \pm 9$ \\
\hline \multirow[t]{6}{*}{ C. geophilum } & no & 10 & P1 & $31 \pm 26$ \\
\hline & no & 10 & $\mathrm{P} 2$ & $45 \pm 22$ \\
\hline & no & 20 & $\mathrm{P} 1+\mathrm{P} 2$ & $38 \pm 25$ \\
\hline & yes & 10 & $\mathrm{P} 1$ & $35 \pm 4$ \\
\hline & yes & 10 & $\mathrm{P} 2$ & $28 \pm 22$ \\
\hline & yes & 20 & $\mathrm{P} 1+\mathrm{P} 2$ & $32 \pm 24$ \\
\hline \multirow[t]{6}{*}{ T. fibrilosa } & no & 10 & P1 & $16 \pm 12$ \\
\hline & no & 10 & P2 & $5 \pm 5$ \\
\hline & no & 20 & $\mathrm{P} 1+\mathrm{P} 2$ & $10 \pm 11$ \\
\hline & yes & 10 & $\mathrm{P} 1$ & $11 \pm 10$ \\
\hline & yes & 10 & $\mathrm{P} 2$ & $15 \pm 10$ \\
\hline & yes & 20 & $\mathrm{P} 1+\mathrm{P} 2$ & $13 \pm 13$ \\
\hline
\end{tabular}

were recorded in the control treatment (Fig. 1; Supplementary Table 1).

The proportion of active mycorrhizae generally followed the pattern of active mycorrhizae density, but with a less pronounced effect of drought. The difference in the proportion of active mycorrhizae between drought-stressed and control plots was highest in 2010 (Fig. 1; Supplementary Table 1). However, the difference between the compared years was not statistically significant (Table 2). No significant effect of drought stress was detected in the proportion of active mycorrhizae, probably due to the large variance of experimental data (Fig. 1; Supplementary Table 1). But two-factor interaction year $\times$ drought stress was statistically significant (LME: $\mathrm{n}=119 ; \mathrm{df}=2 ; p<0.01$; Table 2). In the drought-stressed plots, the proportion of active mycorrhizae was gradually increased contrary to control plots, where the proportion had a decreasing trend (Fig 1; Supplementary Table 1).

Neither dry mass of roots with a diameter up to $1 \mathrm{~mm}$ (Fig. 1; Supplementary Table 1) nor specific 
root length with a diameter up to $1 \mathrm{~mm}$ (Table 3) showed any statistically significant differences between drought-stressed and control parts.

Nine morphotypes were distinguished in samples collected in autumn 2013 (i.e., $4^{\text {th }}$ year of the experiment). Using molecular analyses, we determined 4 species of ectomycorrhizal fungi corresponding to 5 different morphotypes which commonly occurred in the samples: Amphinema byssoides (Pers.) J. Erikss., Cenococcum geophilum Fr., Tylopilus felleus (Bull.) P. Karst. (comprising 2 morphotypes that were merged after molecular identification), and Tylospora fibrillosa (Burt) Donk. These four mycobionts dominated mostly the community and represented $97.2-100 \%$ of the discerned morphotypes on the tested plots in 2013. Other morphotypes occurred sporadically in the samples: one morphotype with low abundance (0-1.4\%) comprised 3 ectomycorrhizal species (Tylopilus felleus, Tylospora fibrillosa, and Thelephora terrestris) and molecular analyses of the remaining three morphotypes (occurring at abundances ranging from $0-1.7 \%, 0-0.3 \%$ and $0-1.5 \%$, respectively) yielded mostly sequences of low quality some of which were related to saprobic or endophytic fungi (e.g., Ganoderma sp., Oidiodendron sp., Cryptococcus sp. etc.) indicating these were partially rotten senescent mycorrhizae or non-mycorrhizal root tips. The representation of the discerned ectomycorrhizal species in the tested plots was quite homogeneous and not influenced significantly by drought and plot (Table 3 ).

\section{Discussion}

Drought stress caused by a rainfall reduction in our study reached an intermediate intensity we assume it was not detrimental to ectomycorrhizae as hyphae of mycorrhizal fungi are able to survive long periods of drought even at extremely shallow water potential values ( $-20 \mathrm{MPa}$ ) (Querejeta et al., 2003). However, using our experimental approach, we cannot exclude groundwater availability putatively attenuating the drought stress regime in deeper mineral soil layers with impact on an overall physiological status of the tested trees.

Induced drought stress leading to changes was more pronounced in Norway spruce seedlings grown under artificial conditions, whether it was a decrease of mycorrhizal colonization in seedlings as soon as exclusion of irrigation for 9 days (Möttönen et al., 2001), 6 days and subsequent 8 days (Möttönen et al., 2005) or 2-4 months in the third and the fifth year (Nilsen et al., 1998). The effect of drought on mycorrhizal colonization within Norway spruce stands (including our study) was not so apparent. On 80-yearsold spruces drought induced by shelters significantly reduced the density of active mycorrhizae, but not the density of nonactive mycorrhizae neither proportion of active mycorrhizae (Pešková et al., 2015). In two 12 years-old spruce stands drought induced by shelters (approx. $40 \%$ of control atmospheric precipitation) had no significant effect on a level of the mycorrhization (determined indirectly on the basis of chitin) between control and drought-stressed. Instead, there was observed considerable dynamics of in the experimental time course (Palátová, 2004). Less obvious effect of drought on mycorrhizae on stands in natural conditions can be due to other environmental factors (including natural dynamics of mycorrhizae), which significantly interact with drought and may blur its impact. Results from our study also show that the dynamics of the density of active and nonactive mycorrhizae differ, probably not only due to the quantitative transition of one form to the other or the influence of drought on their change. The density of active mycorrhizae compared to relatively higher and more fluctuating density of nonactive mycorrhizae can surprisingly indicate a significant fluctuation in the lifetime of active mycorrhizae. High temporal dynamics of the density of active and nonactive mycorrhizae were also observed in previous studies (e. g. Blasius et al., 1989; Pešková, 2007; Pešková et al., 2011).

We should stress that before the beginning of the experiment (spring 2010) the densities of active and nonactive mycorrhizae, the proportion of active mycorrhizae, and dry mass of roots with a diameter up to $1 \mathrm{~mm}$ did not differ significantly in any part of the research plots (see Lorenc, 2012; Supplementary Table 2).

Dry mass of roots with diameter up to $1 \mathrm{~mm}$ in this study was not significantly influenced by drought stress. It is congruent with study on 80 years old spruces in the first and the second year with the same experimental design (Pešková et al., 2015) and in roots with diameter up to $2 \mathrm{~mm}$ on 140 years old spruces after six weeks of water exclusion induced by shelters (Gaul et al., 2008). On the other hand, the influence of drought on root weight has been observed to be negative in roots with diameter up to $1 \mathrm{~mm}$ in spruces 12 years old in all four years of the experiment (Palátová, 2004), in roots with diameter up to $2 \mathrm{~mm}$ in trees 5 years old, exposed to 11 -year reduced watering in greenhouse (Eldhuset et al., 2013) and in young spruce stands in natural conditions, monitored for four years (Konôpka et al., 2013). These contradictory results are suggesting that the response of fine root biomass to drought is not uniform. Similarly, there is a wide variation in the effect of drought on specific root length. Brunner et al. (2015) stated that specific root length usually is not significantly affected in drought-stressed trees which is in agreement with our observation. On the other hand, Puhe (2003) declared that in adverse conditions fine roots of Norway spruce might have 
smaller specific root length and greater amount of the roots due to an increased quantity of necromass. Contrary to our results, Olmo et al. (2014) observed higher specific root length of very fine roots (diameter up to $0.5 \mathrm{~mm}$ ) using seedlings of 10 tree species stressed by severe drought in a greenhouse. The discrepancies among the above-mentioned studies may be partially explained by the different diameter of the analyzed roots but may also reflect other physiological processes such as changes in the composition of associated ectomycorrhizal communities (with a concomitant effect on multiple root parameters including specific root length).

Although the identified spruce ectomycorrhizal species in our study correspond well to those observed by others in the Czech Republic (Peter et al., 2008; Vohník et al., 2013), the community richness was very low. Low diversity of detected fungi may be due to several putative reasons. Firstly, we only analyzed root tips in the upper organic layer leaving thus all ectomycorrhizal species occurring exclusively in the mineral layers undetected. Secondly, a large proportion ( $59 \%$ on average) of microscopically analyzed root tips was of low quality and their unequivocal assignment to a particular morphotype was not possible. After their subtraction approx. 140 root tips per root sample remained and were assigned to the particular morphotypes. With this amount of root tips theoretically, only fungi whose frequency reached at least $2.1 \%$ in the community were detected at $95 \%$ probability level according to Taylor (2002). Rarer species thus might have been overlooked though their functional importance is disputable.

While we have not detected the effect of drought stress on the composition of the ectomycorrhizal community, Shi et al. (2002) observed a significant effect of three months lasting drought (induced by plastic roofs) on the fungal community associated with Fagus sylvatica L. In their study ectomycorrhizal species responded differently to the drought of varied intensity. Using analogous experimental approach to our study, Nickel et al. (2018) detected changes in the ectomycorrhizal community in a mixed beechspruce forest caused by drought with an increase of species having long rhizomorphs. The authors concluded that ectomycorrhizae responded to repeated drought by maintaining or increasing their functionality at the individual root level, but were unable to compensate for quantitative losses at the ecosystem level. On the contrary, Nilsen et al. (1998) observed only C. geophilum was significantly affected by drought (imposed by 2-4 months exclusion of water in the third and the fifth experimental year) in potted Norway spruces in the sixth year of the experiment. We suppose that lack of ectomycorrhizal community changes the fourth year after the drought onset in our study was caused by moderate drought stress and the compensation ability of Norway spruce (the community composition was tested four years after the onset of drought stress).

Intense and sudden stress stimulus may lead to trees damage and inhibition of their growth. Gradual onset of stress, however, allows a physiological adaptation of a plant which may prevent adverse consequences of the stress (Kozlowski \& Pallardy, 2002). On ectomycorrhizal roots, it was demonstrated by Swaty et al. (2004), who reported twice as high colonization of roots by ectomycorrhizal fungi exposed to medium levels of drought stress compared to trees exposed to a low or high level of drought stress in stands of Colorado pinyon (Pinus edulis Engelm.). We assume fine spruce roots in our study were able to compensate for repeated drought stress of intermediate intensity which was reflected in the recovery of the density of active mycorrhizae and no detectable changes of other root characteristics including ectomycorrhizal community composition.

Overall this study demonstrates that fine roots of Norway spruce, including ectomycorrhizae, are able to endure repeated periods of moderate drought stress and compensate for it. Observed differences of root parameters between plots and years indicate that a combination of drought stress intensity and other environmental factors contributed to the mitigation of drought effect on spruce fine roots. Our results underline the necessity to study the effect of drought on a broad severity scale and to monitor both shortand long-term changes of tested tree parameters.

\section{Acknowledgements}

This research was carried out under a grant from the National Agency for Agricultural Research of the Ministry of Agriculture of the Czech Republic (NAZV) - project QH 81136. It was also supported by the Internal Grant Agency of Faculty of Forestry and Wood Sciences Czech University of Life Sciences in Prague - projects GA FLD CZU 20134335, GA FLD CZU 20134339, GA FLD CZU A19/14, and GA FLD CZU B10/17; by projects of the Ministry of Agriculture of the Czech Republic: Resolutions RO0117 (reference number 6779/2017-MZE-14151) and RO0118; by the Czech Academy of Sciences (long-term research development project RVO 67985939), by the Operational Programme Research, Development and Education (OP VVV) of the Ministry of Education, Youth and Sports of the Czech Republic - project EXTEMIT-K (reference number CZ.02.1.01./0.0/0.0/15 _003/0000433), and by Operational Programme Research, Development and Education (OP RDE) - project "EVA4.0" (reference number CZ.02.1.01/0.0/0.0 /16_019/0000803). The authors would like to thank Gale A. Kirking at English Editorial Services, s. r. o. and Dr. Amit Roy for linguistic improvements. 


\section{References}

Agerer R (1987-2012) Colour atlas of ectomycorrhizae. 1st - 15th del. Einhorn-Verlag, Schwäbisch Gmünd, Germany.

Altman J, Fibich P, Santruckova H, Dolezal J, Stepanek P, Kopacek J, Hunova I, Oulehle F, Tumajer J \& Cienciala E (2017) Environmental factors exert strong control over the climate-growth relationships of Picea abies in Central Europe. Science of the Total Environment 609: 506-516. doi:10.1016/j.scitotenv.2017.07.134.

Blasius D, Kottke I \& Oberwinkler F (1989) Spatial and seasonal dynamics of ectomycorrhiza of Picea abies (L.) Karst. in the Black Forest. Agriculture, Ecosystems \& Environment 28: 27-30. doi:10.1016/0167-8809(90)90007-Z.

Bois G, Bertrand A, Piché Y, Fung M \& Khasa DP (2006) Growth, compatible solute and salt accumulation of five mycorrhizal fungal species grown over a range of $\mathrm{NaCl}$ concentrations. Mycorrhiza 16: 99-109. doi:10.1007/s00572-005-0020-y.

Bréda N, Huc R, Granier A \& Dreyer E (2006) Temperate forest trees and stands under severe drought: a review of ecophysiological responses, adaptation processes and long-term consequences. Annals of Forest Science 63: 625-644. doi:10.1051/forest:2006042.

Bréda N \& Badeau V (2008) Forest tree responses to extreme drought and some biotic events: towards a selection according to hazard tolerance? Comptes Rendus Geoscience 340: 651-662. doi:10.1016/j.crte.2008.08.003.

Brunner I, Herzog C, Dawes MA, Arend M \& Sperisen C (2015) How tree roots respond to drought. Frontiers in Plant Science 6: 547. doi:10.3389/ fpls.2015.00547.

Buée M, Vairelles D \& Garbaye J (2005) Year-round monitoring of diversity and potential metabolic activity of the ectomycorrhizal community in a beech (Fagus silvatica) forest subjected to two thinning regimes. Mycorrhiza 15: 235-245. doi:10.1007/s00572-004-0313-6.

Crawley MJ (2007) The R Book. John Wiley \& Sons, New York, USA.

Cudlín P, Kieliszewska-Rokicka B, Rudawska M, Grebenc T, Alberton O, Lehto T, Bakker MR, Børja I, Konôpka B, Leski T, Kraigher H \& Kuyper TW (2007) Fine roots and ectomycorrhizas as indicators of environmental change. Plant Biosystems 141: 406-425. doi:10.1080/11263500701626028.

Di Pietro M, Churin JL \& Garbaye J (2007) Differential ability of ectomycorrhizas to survive drying. Mycorrhiza 17: 547-550. doi:10.1007/s00572007-0113-x.

Eldhuset TD, Nagy NE, Volařík D, Børja I, Gebauer R, Yakovlev IA \& Kronene P (2013) Drought affects tracheid structure, dehydrin expression, and above- and belowground growth in 5-yearold Norway spruce. Plant and Soil 336: 305-320. doi:10.1007/s11104-012-1432-z.

Gardes M \& Bruns TD (1993) ITS primers with enhanced specificity for basidiomycetes - application to the identification of mycorrhizae and rusts. Molecular Ecology 2: 113-118. doi:10.1111/j.1365294X.1993.tb00005.x.

Gaul D, Hertel D, Borken W, Matzner E \& Leuschner C (2008) Effect of experimental drought on the fine root system of mature Norway spruce. Forest Ecology and Management 256: 1151-1159. doi:10.1016/j.foreco.2008.06.016.

Gryndler M, Baláž M, Hršelová H, Jansa J \& Vosátka M (2004) Mykorhizní symbióza: o soužití hub s kořeny rostlin. Academia, Praha, Czech Republic.

Holuša J, Pešková V, Vostrá L \& Pernek M (2009) Impact of mycorrhizal inoculation on spruce seedling: comparisons of a 5 - year experiment in forests infested by honey fungus. Periodicum Biologorum 111: 413-417. doi:10.18054/ pb.2015.117.4.3839.

ISO/DIS 10390 (1994) Soil quality - Determination of $\mathrm{pH}$. International Organization for Standardization.

Kernaghan G (2005) Mycorrhizal diversity: cause and effect? Pedobiologia 49: 511-520. doi:10.1016/j. pedobi.2005.05.007.

Kivlin SN, Emery SM \& Rudgers JA (2013) Fungal symbionts alter plant responses to global change. American Journal of Botany 100: 1445-1457. doi:10.3732/ajb.1200558.

Kjøller R \& Clemmensen KE (2009) Belowground of ectomycorrhizal fungal communities respond to liming in three southern Swedish coniferous forest stands. Forest Ecology and Management 257: 2217-2225. doi:10.1016/j.foreco.2009.02.038.

Koide RT, Sharda JN, Herr JR \& Malcolm GM (2008) Ectomycorrhizal fungi and the biotrophy-saprotrophy continuum. New Phytologist 178: 230233. doi:10.1111/j.1469-8137.2008.02401.x.

Konôpka B \& Takáčová E (2010) Effects of liming and NPK fertilization on the soil and fine roots in a Norway spruce stand, Nizke Tatry Mts. Ekologia Bratislava 29: 28-39. doi:10.4149/ ekol_2010_01_28.

Konôpka B, Pajtík J \& Malová M (2013) Fine root standing stock and production in young beech and spruce stands. Forestry Journal 59: 163-171. doi:10.2478/v10114-011-0023-x.

Korkama T, Pakkanen A \& Pennanen T (2006) Ectomycorrhizal community structure varies among Norway spruce (Picea abies) clones. New Phytologist 171: 815-824. doi:10.1111/j.14698137.2006.01786.x. 
Kozlowski TT \& Pallardy SG (2002) Acclimation and adaptive responses of woody plants to environmental stresses. The Botanical Review 68: 270334. doi:10.4149/ekol_2010_01_28.

Landeweert R, Veenman C, Kuyper TW, Fritze H, Wernars K \& Smit E (2003) Quantification of ectomycorrhizal mycelium in soil by real-time PCR compared to conventional quantification techniques. FEMS Microbiology Ecology 45: 283-292. doi:10.1016/S0168-6496(03)00163-6.

Lehto T (1994) Effect of soil pH and calcium on mycorrhizas of Picea abies. Plant and Soil 163: 69-75. doi:10.1007/BF00033942.

Lehto T \& Zwiazek JJ (2011) Ectomycorrhizas and water relations of trees: a review. Mycorrhiza 21: 71-90. doi:10.1007/s00572-010-0348-9.

Lindberg M \& Johannson M (1992) Resistance of Picea abies seedlings to infection by Heterobasidion annosum in relation to drought stress. Forest Pathology 22: 115-124. doi:10.1111/j.1439-0329.1992. tb01438.x.

Lindner M, Garcia-Gonzalo J, Kolström M, Green T, Reguera R, Maroschek M, Seidl R, Lexer MJ, Netherer S, Schopf A, Kremer A, Delzon S, Barbati A, Marchetti M \& Corona P (2008) Impact of climate change of European forests and options for adaptation. Report to the European Commision Directorate-General for Agriculture and Rural Development. https://ec.europa.eu/agriculture/ sites/agriculture/files/external-studies/2008/euro-forests/full_report_en.pdf.

Lindner $M$, Maroschek $\bar{M}$, Netherer $S$, Kremer A, Barbati A, Garcia-Gonzalo J, Seidl R, Delzon S, Corona P, Kolström M, Lexer MJ \& Marchetti M (2010) Climate change impacts, adaptive capacity and vulnerability of European forest ecosystems. Forest Ecology and Management 259: 698-709. doi:10.1016/j.foreco.2009.09.023.

Lorenc F (2012) Vliv sucha na růst mykorhiz u smrku ztepilého. Diplomová práce. Fakulta životního prostředí, Česká zemědělská univerzita v Praze, Praha, Czech Republic.

Möttönen M, Aphalo PJ \& Lehto T (2001) Role of boron in drought resistance in Norway spruce (Picea abies) seedlings. Tree Physiology 21: 673-681. doi:10.1093/treephys/21.10.673.

Möttönen M, Lehto T, Rita H \& Aphalo PJ (2005) Recovery of Norway spruce (Picea abies) seedlings from repeated drought as affected by boron nutrition. Trees 19: 213-223. doi:10.1007/s00468004-0384-1.

Němeček J, Vokoun J, Smejkal J, Macků J, Kozák J, Němeček K \& Borůvka L (2004) Elektronický taxonomický klasifikační system půd v ČR. Česká zemědělská univerzita v Praze, Praha, Czech Republic. http://klasifikace.pedologie.cz/.
Nickel UT, Weikl F, Kerner R, Schäfer C, Kallenbach C, Munch JC \& Pritsch K (2018) Quantitative losses vs. qualitative stability of ectomycorrhizal community responses to 3 years of experimental summer drought in a beech-spruce forest. Global Change Biology 24: e560-e576. doi:10.1111/ gcb.13957.

Nilsen P, Børja I, Knutsen H \& Brean R (1998) Nitrogen and drought effects on ectomycorrhizae of Norway spruce (Picea abies (L.) Karst.). Plant and Soil 198: 179-184. doi:10.1023/A:1004399303192.

Nowotny I, Dähne J, Klingelhöfer D \& Rothe GM (1998) Effect of artificial soil acidification and liming on growth and nutrient status of mycorrhizal roots of Norway spruce (Picea abies (L.) Karst.). Plant Soil 199: 29-40. doi:10.1023/A:1004265511068.

$\varnothing$ kland B \& Berryman A (2004) Resource dynamic plays a key role in regional fluctuation of the spruce bark beetle Ips typographus. Agricultural and Forest Entomology 6: 141-146. doi:10.1111/ j.1461-9555.2004.00214.x.

Olmo M, Lopez-Iglesias B \& Villar R (2014) Drought changes the structure and elemental composition of very fine roots in seedlings of ten woody tree species. Implications for a drier climate. Plant Soil 384: 113-129. doi:10.1007/s11104-014-2178-6.

Palátová E (2004) Effect of increased nitrogen depositions and drought stress on the development of young Norway spruce Picea abies (L.) Karst. Stands. Dendrobiology 51: 41-45.

Pekár S \& Brabec M (2012) Modern analysis of biological data. 2. Linear models with correlations in R. Masaryk University Press, Brno, Czech Republic.

Pešková V \& Soukup F (2006) Houby vázané na kořenové systémy: metodické prrístupy ke studiu. Review. Zprávy lesnického výzkumu 51: 279-286.

Pešková V (2007) Changes in the mycorrhizal status of some mountain spruce forests. Journal of Forest Science 53: 82-88. doi:10.17221/2160-JFS.

Pešková V, Landa J \& Soukup F (2011) Findings regarding ectotrophic stability of Norway spruce forest of Krkonoše and Orlické Mts. based on mycorrhiza studies. Journal of Forest Science 57: 500-513. doi:10.17221/139/2010-JFS.

Pešková V, Lorenc F, Modlinger R \& Pokorná V (2015) Impact of drought and stand edge on mycorrhizal density on the fine roots of Norway spruce. Annals of Forest Research 58: 245-257. doi:10.15287/afr.2015.364.

Peter M, Ayer F, Cudlín P \& Egli S (2008) Belowground ectomycorrhizal communities in three Norway spruce stands with different degrees of decline in the Czech Republic. Mycorrhiza 18: 157-169. doi:10.1007/s00572-008-0166-5. 
Peter M, Kohler A, Ohm RA, Kuo A, Krützmann J, Morin E, Arend M, Barr KW, Binder M, Choi C, Clum A, Copeland A, Grisel N, Haridas S, Kipfer T, LaButti K, Lindquist E, Lipzen A, Maire R, Meier B, Mihaltcheva S, Molinier V, Murat C, Pöggeler S, Quandt CA, Sperisen C, Tritt A, Tisserant E, Crous PW, Henrissat B, Nehls U, Egli S, Spatafora JW, Grigoriev IV \& Martin FM (2016) Ectomycorrhizal ecology is imprinted in the genome of the dominant symbiotic fungus Cenococcum geophilum. Nature Communications 7: 12662. doi:10.1038/ ncomms12662.

Piculell BJ, Hoeksema JD \& Thompson JN (2008) Interactions of biotic and abiotic environmental factors in an ectomycorrhizal symbiosis, and the potential for selection mosaics. BMC Biology 6: 23. doi:10.1186/1741-7007-6-23.

Porcel R \& Ruiz-Lozano JM (2004) Arbuscular mycorrhizal influence on leaf water potential, solute accumulation, and oxidative stress in soybean plants subjected to drought stress. Journal of Experimental Botany 55: 1743-1750. doi:10.1093/ jxb/erh188.

Pretzsch H, Schütze G \& Uhl E (2013) Resistance of European tree species to drought stress in mixed versus pure forests: evidence of stress release by inter-specific facilitation. Plant Biology 15: 483495. doi:10.1111/j.1438-8677.2012.00670.x.

Puhe J (2003) Growth and development of the root system of Norway spruce (Picea abies) in forest stands - a review. Forest Ecology and Management 175: 253-273. doi:10.1016/S03781127(02)00134-2.

R Core Team (2015) A language and environment for statistical computing. R Foundation for Statistical Computing, Vienna, Austria. www.R-project.org/.

Querejeta J, Egerton-Warburton LM \& Allen MF (2003) Direct nocturnal water transfer from oaks to their mycorrhizal symbionts during severe soil drying. Oecologia 134: 55-64. doi:10.1007/ s00442-002-1078-2.

Shi L, Guttenberger M, Kottke I \& Hampp R (2002) The effect of drought on mycorrhizas of Beech (Fagus sylvatica L.): changes in community structure, and the content of carbohydrates and nitrogen storage bodies of the fungi. Mycorrhiza 12: 303-311. doi:10.1007/s00572-002-0197-2.

Swaty RL, Deckert RJ, Whitham TG \& Gehring CA (2004) Ectomycorrhizal abundance and commu- nity composition shifts with drought: predictions from tree rings. Ecology 85: 1072-1084. doi:10.1890/03-0224.

Taylor AFS (2002) Fungal diversity in ectomycorrhizal communities: sampling effort and species detection. Plant and Soil 244: 19-28. doi:10.1023/A:1020279815472.

Turčáni M, Holuša J, Kalinová B, Hlásný T, Nakládal $\mathrm{O}$, Modlinger R, Matoušek $\mathrm{P}$, Mašánková $\mathrm{K}$, Kováŕová I, Zajíčková L, Nádraská M, Krupa M, Lukášová K, Lubojacký J, Půža V \& Zahradník P (2010) Výzkumný projekt NAZV- QH81136. Studium a optimalizace skutečné efektivity obranných opatření proti lýkožroutu smrkovému v různých gradačních fázích. Neperiodické zpráva za rok 2010. Česká zemědělská univerzita v Praze, Praha, Czech Republic.

Vohník M, Mrnka L, Lukešová T, Bruzone MC, Kohout P \& Fehrer J (2013) The cultivable endophytic community of Norway spruce ectomycorrhizas from microhabitats lacking ericaceous hosts is dominated by ericoid mycorrhizal Meliniomyces variabilis. Fungal Ecology 6: 281-292. doi:10.1016/j.funeco.2013.03.006.

Von Alten H \& Rossbach B (1989) Mycorrhiza development in 4 forest dieback stands in West Germany: agriculture, ecosystems and environmet. Ecological and applied aspects of ecto- and endomycorrhizal associations. European Symposium on Mycorrhizae, 5-9.08.1988, Prague (ed. by V Mejstř́ík) Academia, Praha, Czech Republic, pp. 13-19.

White TJ, Bruns TD, Lee SW \& Taylor JW (1990) Amplification and direct sequencing of fungal ribosomal RNA genes for phylogenetics: PCR protocols. A guide to methods and applications (ed. by MA Innis, DH Gelfand, JJ Sninsky \& TJ White) Academic Press, New York, USA, pp. 315-322.

Zajíčková L, Nádraská M, Bř́izová R \& Procházková D (2011) Norway spruce water use under drought stress conditions: Biotic risks and climate change in forests. 10th IUFRO Workshop of WP 7.03.10 "Methodology of Forest Insect and Disease Survey in Central Europe", 20-23.09.2010 (ed. by H Delb \& S Pontuali) Fakultät für Forst- und Umweltwissenschaften der Albert-Ludwigs-Universität, Freiburg, Germany, pp. 26-30. 